\title{
気管内挿管麻酔後に生じた両側喉頭麻痺症例
}

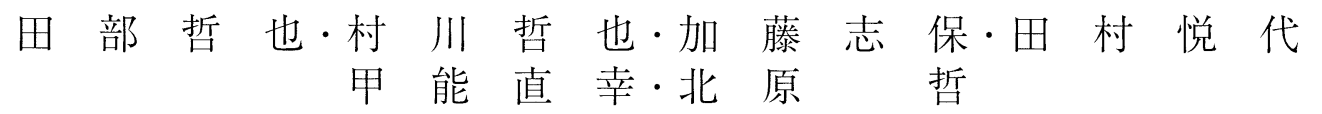

\section{A Case of Bilateral Laryngeal Nerve Paralysis after Endotracheal Intubation}

\author{
Tetsuya Tanabe, Tetsuya Murakawa, Shiho Katoh, \\ Etsuyo Tamura, Naoyuki Kohno and Satoshi Kitahara
}

\begin{abstract}
A 58-year-old woman with diffuse goiter underwent an expansive laminectomy of the spinal canal under general anesthesia in the prone and head down position. Her trachea was intubated uneventfully with a spiral tube (7.0-mm I.D.), and the cuff was filled with air $(3 \mathrm{ml})$. It took 2 hours and 40 minutes to finish the surgical procedure. After extubation, stridor was noticed. Flexible laryngoscopic examination revealed stenosis of the glottis caused by bilateral laryngeal nerve paralysis, and a tracheotomy was performed. The paralysis disappeared within two weeks and the tracheal stoma was closed. The cause of the laryngeal nerve paralysis after endotracheal intubation is usually considered to be a local circulatory disorder produced by the endotracheal tube and cuff. In this case, however, the patient with diffuse goiter condition and the head down position may have been causes of the paralysis, because the other possible factors were negligible.
\end{abstract}

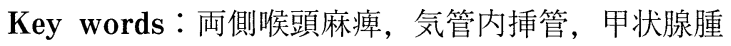

$$
\text { は じめに }
$$

気管内挿管麻酔に続発するいわゆる挿管性喉頭麻痺の報 告は多いが，ほとんどが嗄声を主訴とする片側麻疩であり， 両側喉頭麻痺は比較的まれである。今回，気管内挿管麻酔 後に生じた両側喉頭麻痺症例を経験したので, 文献的考察 を加えて報告する。

\section{症}

例

症例 : 58歳, 女性

主訴：喘鳴（抜管直後より発生）

既往歴：橋本病

現病歴：頸椎症性頸髄症（C2-C3）の診断で, 当院整形 外科にて 2000．9.13気管内括管・全身麻酔で脊柱管拡大 術が施行された。挿管操作は特に問題なく, 螺旋チューブ （7.0mm ID）が気管内挿管され，空気 $3 \mathrm{ml}$ をカフに注入 し, 右口角に $21 \mathrm{~cm}$ の深さで固定された。手術の体位は腹 臥位で頸部は前屈位であった（図 1 )。手術時間は 2 時間 40分, 挿管時間は約 3 時間であった. 術中の水分バランス

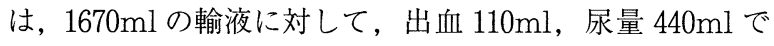
あった. 術後, 仰臥位にして麻酔から覚醒後抜管された。 抜管直後より吸気性喘鳴が認められたため, 当科に診察依 頼があった。
現症：ファイバースコープで上気道を観察したところ， 両側声帯の外転障害による声門狭窄を認めた。声門間隙は $2 \sim 3 \mathrm{~mm}$ 程度であった（図 2 ). 発声による両側声帯の 内転には問題はなかった。

体格は身長 $149 \mathrm{~cm}$ ，体重 $50 \mathrm{~kg}$ であった。また，橋本病 による甲状腺のびまん性腫大が認められていた（図 3 )。な お, 反回神経周囲への手術操作は全く加わっていなかった。

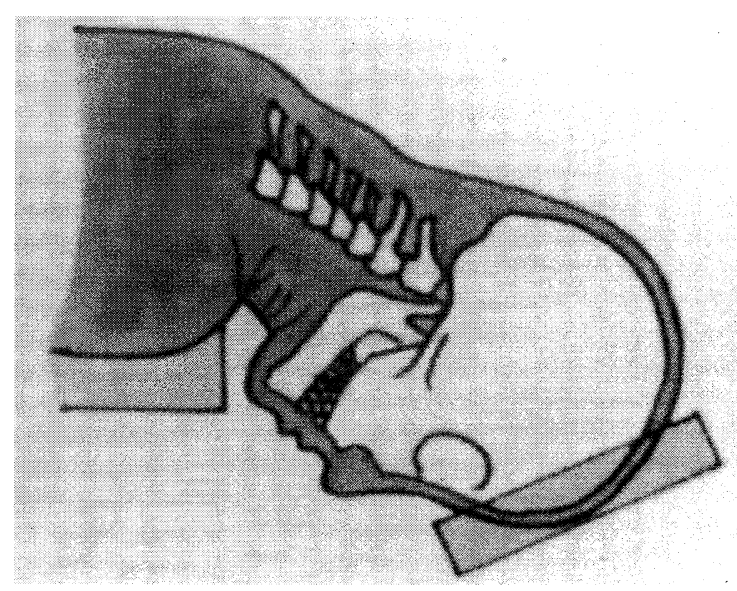

図 1 術中の体位 腹臥位で頸部は前屈位であった 


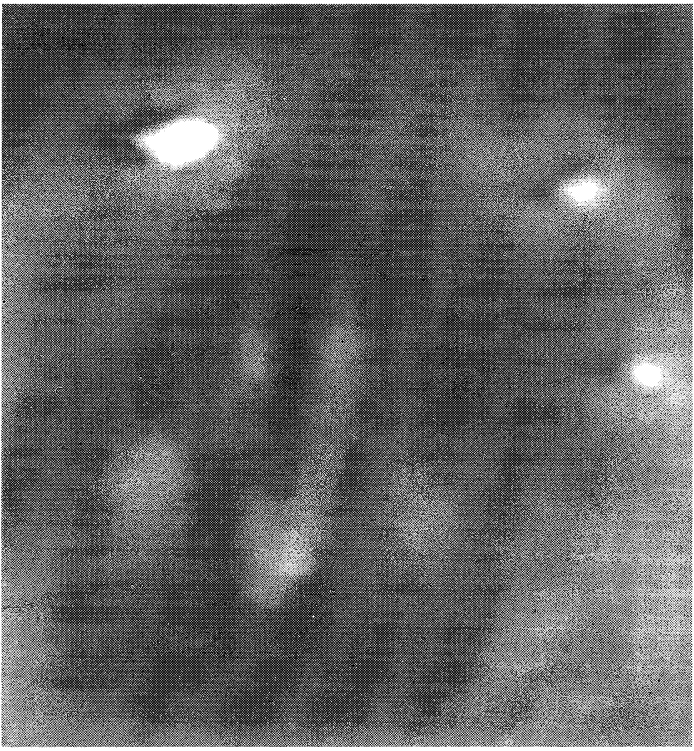

図 2 初診時の喉頭所見 両側声帯の外転障害による声門狭窄を認め, 声門 間隙は 2〜3 $\mathrm{mm}$ であった

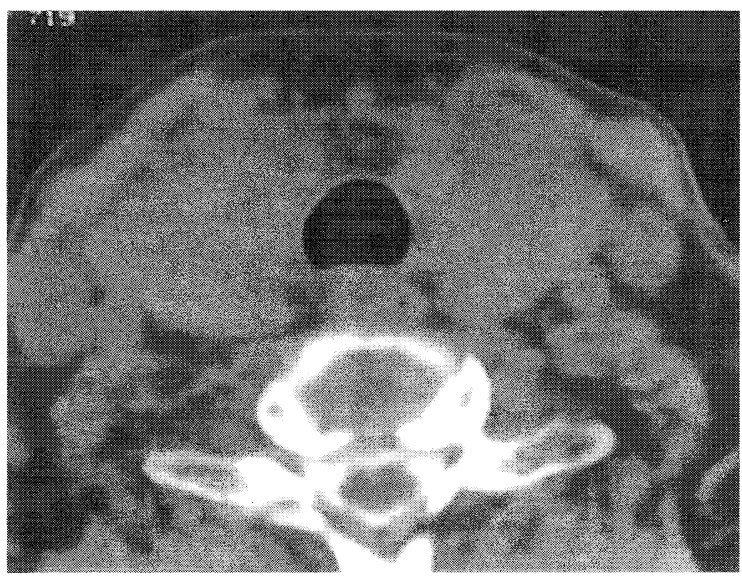

図 3 頸部 CT 所見

橋本病による甲状腺のびまん性腫大を認めた

経過：自覚的な呼吸苦はなかったが, 数十分の経過観察 後も喘鳴や喉頭所見に変化はなく, 挿管性両側喉頭麻瘏と 考えた. 麻酔科医, 整形外科医と協議し, 気管切開術を施 行することが最も安全であると判断し, 患者本人と家族の 同意を得たうえで，気管内择管による全身麻酔下に気管切 開術を施行した。

術後 1 週間はステロイドを漸減で投与した。術後 5 日目 頃より声門の開大傾向を認めた. 14日目には声帯運動は正 常に回復したため（図４）気管孔を閉鎖した. 以後経過は 良好である。

$$
\text { 考察 }
$$

200 症例以上の喉頭麻痺を集計した, 最近 15 年間の報 告 ${ }^{1 \sim 6)}$ から挿管性喉頭麻痺を表にまとめた。

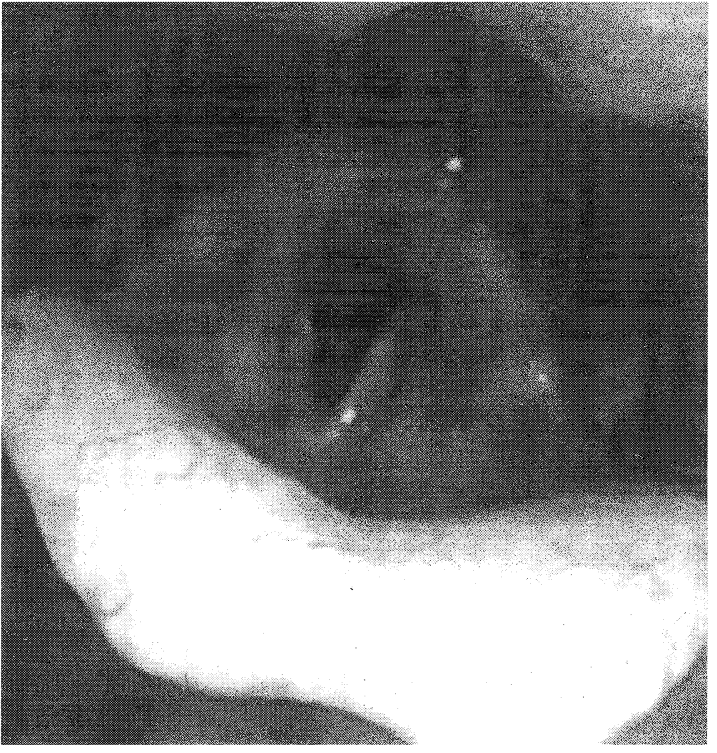

図4発症後14日目の喉頭所見 声带運動は正常に回復した

表 1 挿管性喉頭麻痺の統計

\begin{tabular}{|c|c|c|c|c|c|c|c|}
\hline \multirow{2}{*}{ 報告者 } & \multirow{2}{*}{ 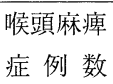 } & \multicolumn{6}{|c|}{ 挿管性喉頭麻瘏 } \\
\hline & & 男 & 女 & 左側 & 右側 & 両側 & 計 \\
\hline 長山ら & 661 & 34 & 21 & 40 & 13 & 2 & 55 \\
\hline 米川ら & 300 & 21 & 15 & 23 & 13 & 0 & 36 \\
\hline 黑川ら & 253 & 10 & 2 & 5 & 6 & 1 & 12 \\
\hline 久ら & 290 & 12 & 4 & 12 & 4 & 0 & 16 \\
\hline 広瀬ら & 1000 & 不 & 明 & 38 & 16 & 0 & 54 \\
\hline 北原ら & 365 & 14 & 10 & 18 & 6 & 0 & 24 \\
\hline 計 & 2869 & 91 & 52 & 136 & 58 & 3 & 197 \\
\hline
\end{tabular}

全喉頭麻㾝症例数は2869症例で，うち挿管性喉頭麻瘏は 197例（5.1\%）であった。性差は91：52で男性に多く，麻 痺側は左側が多く136例 $(69.0 \%)$, 右側は58例 (29.5\%) であった。両側喉頭麻痺は 3 例のみで, 喉頭麻痺全体の 0.1\%（3/2869），挿管性喉頭麻痺の1.5\%（3/197）であり， 発生頻度はまれといえる。

年齢・性は50～60台の男性に多いとされているが ${ }^{3-6)}$, これはこの年代の男性の手術の絶対数が多いためとも考え られる。術式としては腹部の手術後に多いとされてお $\eta^{1,3,4,5)}$, これに関しては腹部の手術の絶対数からみた 発生率においても高率であると報告されている3，7). また， 挿管麻酔1000 2000件に 1 例の発生頻度とされている ${ }^{3 \sim 5)}$. 治療は, ビタミン剤, 神経賦活剂, 循環改善剂, ステロ イド等の投与による保存的治療が原則的に行われるが, 無 治療で経過をみる場合もある ${ }^{3,4)}$. 本症例では, 自覚的な 呼吸苦はなかったものの喘鳴が持続するため, 気管切開を 施行しステロイドの投与も行った，挿管性両側喉頭麻瘏症 例において気管切開を行ったとする報告はない. 本症例も その後の経過で声門狭窄の増悪は認められなかったため, 
結果的には気管切開は不要であったかもしれない.しかし， 気管内挿管麻酔からの覚醒直後の状況であったことを考慮 すると，気管切開は行うべきであったと考えている．

予後は良好とされており，今回の集計で予後の記載のあっ た66側中声帯運動が回復したものは59側（89\%）であった. 回復までの期間は $3 \sim 4$ ケ月以内とされている ${ }^{3 \sim 5)}$. 両側 喉頭麻痺の 3 例で予後の記載があった 1 例については, 1 側は 2 ケ月後に回復し, 他側は 2 年後も回復していなかっ $た^{3)}$. 本症例では, 術後 5 日目頃より声門の開大傾向を認 め, 14日目には声帯運動は正常となり, 比較的早期に回復 した。初診時に, 発声による両側声帯の内転が認められて いたことからも, 反回神経の障害程度は軽度であったもの と推測された。

挿管性喉頭麻痺の発生機序は, 機械的圧迫による反回神 経への血流障害や直接の反回神経への障害とされており, これを助長する要因として, 気管内チューブのサイズ不適 合や浅すぎる位置, カフの過膨脹, 長時間の抻管, 頸部の 伸展や屈曲, 低アルブミン血症等があげられている5).

本症例では, 標準的なサイズの気管内チューブを用いチュー ブの深さも十分に配慮されていた. カフ圧については, 注 入した空気は $3 \mathrm{ml}$ と適切であったが, 亜酸化窒素吸入に よる術中のカフ圧上昇があった可能性は否定できない.た だし, 気管内チューブが浅すぎる場合以外は, カフの過膨 脹が喉頭麻痺の原因となることは少ないとされており ${ }^{8)}$, カフの問題もなかったと考えた。挿管時間は 3 時間であり 特に長時間ではなかった。また，術前検査における血清ア ルブミン值は正常であり, 術中出血も $110 \mathrm{ml}$ であったの で，低アルブミン血症を生じていた可能性もなかったと考 えた。

本症例に扔ける麻痺発症の要因として, 術中体位が頸部 前屈位であったこと, 橋本病による両側甲状腺のびまん性 腫大が存在したことを考えた。すなわち，カフが位置して いた部位において, 反回神経はいわゆる気管食道溝を走行 しており，外側には気管食道溝を覆うように甲状腺が存在 していた，甲状腺が腫大していたことと頸部前屈により，
甲状腺を介して外側から気管食道溝に対する圧力が加わっ たことで，カフ圧による内側からの圧力に問題がなかった にもかかわらず，全体としての機械的圧迫が麻痺を生ずる レベルに達したものと推察した. 気管内チューブのサイズ や位置，カフ圧，挿管時間等に問題がなくても，頸部前屈 や甲状腺腫大により反回神経周囲への機械的圧迫が起こり やすい状況が生じていた可能性が考えられた。

$$
\text { ま と め }
$$

挿管性両側喉頭麻痺の 1 例を報告した。頸部前屈位と甲 状腺腫が喉頭麻痺発症の要因であったと推察した。

本論文の要旨は第13回日本喉頭科学会において報告した。

\section{参 考 文 献}

1）長山郁生ほか：過去 17 年間にみられた反回神経麻痺 の臨床統計．耳展２9(5)：559～567, 1986.

2）米川紘子ほか：反回神経麻痺の臨床統計的観察。喉 頭 1(2)：139 145, 1989.

3）黑川浩伸ほか：挿管性反回神経麻瘏症例の統計的観 察. 耳鼻 36（補 1 ）：175 177, 1990.

4）久 育男ほか：挿管性反回神経麻疾症例の検討。耳 鼻 36（補 1 )：171 174, 1990 .

5）廣瀬 肇：原因的考察（臨床統計）。喉頭麻瘒（第 1 版)，(廣瀬肇，石井英男編）１27～144，文光堂， 東京, 1992 .

6）北原 哲ほか：喉頭麻痺症例の臨床統計的観察．耳 鼻臨床 91(6)：623～629, 1998

7）進武 幹ほか：気管内挿管麻酔後にみられる反回神 経麻痺について。耳鼻 $21 ： 39 \sim 42,1975$.

8）鈴木直美ほか：術後嗄声 ·咽頭痛へのカフ圧の影響. 麻酔 $48(10): 1091 \sim 1095,1999$.

別刷請求先 干 359-8513 埼玉県所沢市並木 3-2 防衛医科大学校耳鼻咽喉科学講座 田部哲也 